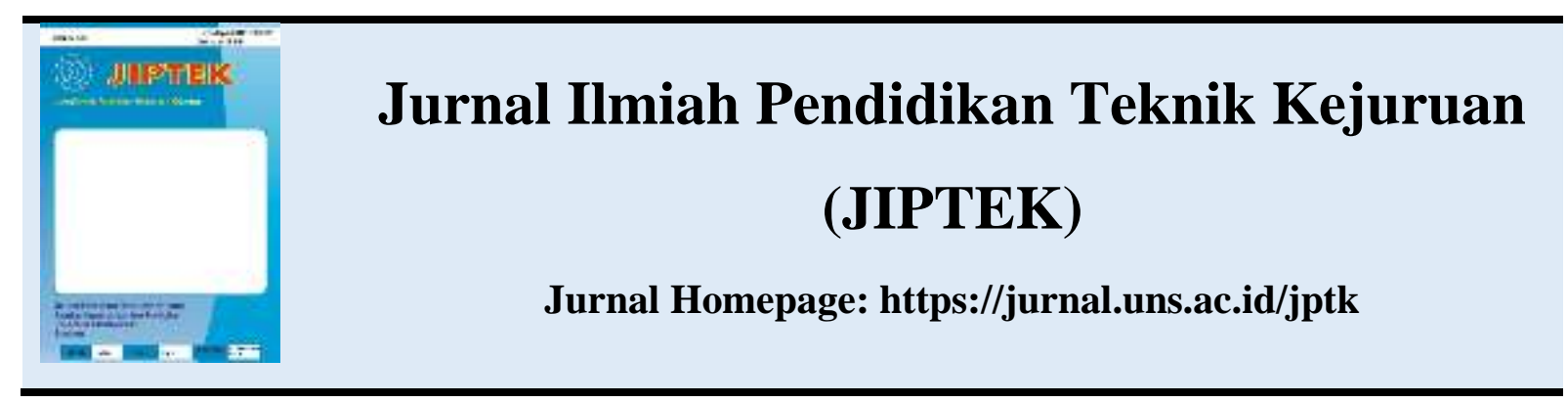

\title{
PENERAPAN MODEL PEMBELAJARAN GROUP INVESTIGATION DAN MEDIA PEMBELAJARAN VIRTUAL BOX UNTUK MENINGKATKAN KEAKTIFAN DAN HASIL BELAJAR SISWA PADA MATA PELAJARAN SISTEM OPERASI KELAS X MULTIMEDIA SMK N 6 SURAKARTA
}

\author{
${ }^{1}$ Rini Umbarwati, ${ }^{1}$ Basori, dan ${ }^{1}$ Taufiq Lilo Adi Sucipto \\ ${ }^{1}$ Program Studi Pendidikan Teknik Informatika dan Komputer Universitas Sebelas Maret \\ *Korespondensi, e-mail: riniumbarwati@gmail.com
}

\begin{abstract}
Abstrak
Penelitian ini bertujuan untuk mengetahui apakah penerapan model pembelajaran Group Investigation dan media pembelajaran Virtual Box dapat meningkatkan keaktifan dan hasil belajar siswa pada mata pelajaran sistem operasi kelas X Multimedia (MM) SMK N 6 Surakarta. Penelitian ini merupakan penelitian tindakan kelas dengan menggunakan dua siklus, disetiap siklusnya terdiri dari perencanaan, pelaksanaan, observasi, dan refleksi kegiatan belajar mengajar. Subjek penelitian ini adalah siswa kelas X MM1 SMK N 6 Surakarta yang berjumlah 32 siswa. Teknik pengumpulan data dengan menggunakan wawancara, observasi, dokumentasi dan tes. Sedangkan analisis data dilaksanakan dengan cara analisis komparatif dan deskriptif kualitatif. Penelitian tindakan kelas ini dilaksanakan dari bulan Desember 2015 sampai bulan Juni 2016. Hasil penelitian menunjukkan bahwa penerapan model pembelajaran Group Investigation dan media pembelajaran Virtual Box dapat meningkatkan keaktifan dan hasil belajar siswa pada mata pelajaran sistem operasi. Hal ini dapat dibuktikan pada kegiatan observasi prasiklus, presentase keaktifan siswa sebesar 52,87\%, setelah penerapan model pembelajaran Group Investigation dan media pembelajaran Virtual Box pada siklus I meningkat $77,87 \%$, kemudian di siklus II meningkat sampai $86,72 \%$. Sedangkan hasil belajar siswa juga terjadi peningkatan dari nilai tes setiap siklus. Pada prasiklus rata-rata hasil belajar untuk ranah kognitif sebesar $62,5 \%$, afektif $65,27 \%$, dan psikomotor $73,44 \%$. Rata-rata hasil belajar meningkat pada ranah kognitif menjadi $73,38 \%$, afektif $71,06 \%$, dan psikomotor $75 \%$ setelah penerapan model pembelajaran Group Investigation dan media pembelajaran Virtual Box pada siklus I. Pada siklus II meningkat untuk ranah kognitif menjadi $87,5 \%$, afektif $82,52 \%$, dan psikomotor $80,47 \%$. Kesimpulan penelitian bahwa penerapan model pembelajaran Group Investigation dan media pembelajaran Virtual Box dapat meningkatkan keaktifan dan hasil belajar siswa pada mata pelajaran sistem operasi kelas X MM SMK N 6 Surakarta.
\end{abstract}

Kata kunci: keaktifan belajar, hasil belajar, Group Investigation, Virtual Box, sistem operasi.

\section{Abstract}

This research aims to know whether the implementation of Group Investigation learning model and Virtual Box learning media can increase students activeness and learning achievement on the subject of operating system class X Multimedia (MM) SMK N 6 Surakarta. This research used classroom action research with two cycles, each cycle consisted of planning, implementation, observation, and reflection of teaching and learning activities. The subject of this research is the students of class X MMI 
SMK N 6 Surakarta which numbered 32 students. Data collection technique that used were interview, observation, documentation and test. Meanwhile analysis technique implemented through comparative analysis and descriptive qualitative. This class action research carried out from December 2015 until June 2016. The result of research shows that the implementation of Group Investigation learning model and Virtual Box learning media can increase students activeness and learning achievement on the operating system subject. This can be proved on the pre-cycle activities observation, the percentage of students activeness is 52,87\%, after implementation of Group Investigation learning model and Virtual Box in the first cycle increased by $77,87 \%$, then in the second cycle increased to $86,72 \%$. While the result of students learning achievement also increased from the value of each cycle test. On pre-cycle the average learning achievement for cognitive domain 62,5\%, affective 65,27\%, and psychomotor $73,44 \%$. The average of learning achievement increased for cognitive domain became 73,38\%, affective $71,5 \%$, and psychomotor $75 \%$ after the implementation of Group Investigation learning model and Virtual Box at the first cycle. At the second cycle increased for cognitive domain to 87,5\%, affective $82,52 \%$, and psychomotor $80,47 \%$. Research conclusion that the implementation of Group Investigation learning model and Virtual Box learning media could increase the students activeness and learning achievement on the subject of operating system class X MM SMK N 6 Surakarta.

Keyword: learning activeness, learning achievement, Group Investigation, Virtual Box, operating system.

\section{PENDAHULUAN}

Sistem operasi adalah salah satu mata pelajaran untuk siswa Sekolah Menengah Kejuruan (SMK) program studi program keahlian Teknik Komputer dan Informatika (TKI) semua paket keahlian yaitu Rekayasa Perangkat Lunak (RPL), Teknik Komputer Jaringan (TKJ), dan Multimedia (MM). Hal ini karena mata pelajaran sistem operasi mempelajari tentang perangkat lunak yang bertugas untuk melakukan kontrol dan manajemen perangkat keras dan juga operasioperasi dasar sistem, termasuk menjalankan software aplikasi seperti programprogram pengolah data yang bisa digunakan untuk mempermudah kegiatan pengguna komputer yang menjadi dasar untuk siswa program studi keahlian teknologi informasi dan komunikasi.

Di SMK N 6 Surakarta untuk program studi keahlian teknologi informasi dan komunikasi, paket keahlian yang tersedia yaitu Multimedia yang pada semester 1 mata pelajaran sistem operasi membahas seluk beluk mengenai sistem operasi Windows. Pada semester 2 yang akan dipelajari adalah sistem operasi Linux. Menurut penelitian awal yang dilaksanakan peneliti, masalah yang ada pada siswa kelas $\mathrm{X}$ Multimedia (MM) SMK N 6 Surakarta untuk mata pelajaran sistem operasi adalah kurangnya keaktifan dan hasil belajar siswa dalam mengikuti proses pembelajaran. Hal ini ditunjukkan ketika proses belajar mengajar berlangsung, siswa melakukan aktivitas lain seperti membuka sosial media ataupun mengobrol dengan temannya. Selain itu jika guru memberikan tugas merangkum, siswa lebih memilih meminta file ringkasan materi dari guru yang mengajar daripada membaca kemudian membuat ringkasan sendiri di buku catatannya serta dari data observasi keaktifan siswa yang menunjukkan bahwa keaktifan belajar siswa rendah dengan rata-rata sebesar 52,87\%. Capaian hasil belajar juga tidak maksimal yang ditunjukkan dari presentase ketuntasan hasil belajar pada pratindakan sebesar $18,75 \%$ untuk ranah kognitif, $21,87 \%$ ranah afektif, dan $43,75 \%$ ranah psikomotor.

Berdasarkan masalah tersebut, maka perlu diterapkan model pembelajaran untuk meningkatkan keaktifan dan hasil belajar siswa dengan menerapkan model pembelajaran Group Investigation dan media pembelajaran Virtual Box. Dengan model Group Investigation siswa diberi kesempatan untuk bersikap ilmiah dengan mengembangkan rasa ingin tahu, jujur, terbuka, tekun, jujur, dan teliti akan membuka dirinya untuk berinteraksi sosial (Istikomah, Hendratto \& Bambang, 2010). Hasil penelitian Syamsuri, Maman, dan Helga (2010), model pembelajaran Group Investigation dapat meningkatkan hasil belajar peserta didik dan kemampuannya memahami materi mata pembelajaran. Model pembelajaran Group Investigation mampu meningkatkan sikap ilmiah siswa (Istikomah, dkk, 2010). Sedangkan penggunaan media Virtual Box adalah untuk mempermudah siswa dalam memahami materi terutama untuk materi 
sistem operasi open source karena mayoritas pada komputer ataupun laptop disekolah juga milik pribadi siswa menggunakan sistem operasi closed source (Windows) dan juga siswa tertarik dalam memperhatikan proses pembelajaran jika disampaikan melalui media yang inovatif.

Tujuan penelitian adalah (1) untuk mengetahui apakah penerapan model pembelajaran Group Investigation dan media pembelajaran Virtual Box dapat meningkatkan keaktifan belajar siswa pada mata pelajaran sistem operasi kelas X MM SMK N 6 Surakarta, (2) untuk mengetahui apakah penerapan model pembelajaran Group Investigation dan media pembelajaran Virtual Box dapat meningkatkan hasil belajar siswa pada mata pelajaran sistem operasi kelas X MM SMK N 6 Surakarta, (3) menerapkan pembelajaran Group Investigation dan media pembelajaran Virtual Box untuk meningkatkan keaktifan dan hasil belajar siswa kelas X MM SMK N 6 Surakarta.

Model pembelajaran Group Investigation (GI) pertama kali dikembangkan oleh Sharan dan Sharan (1976) merupakan salah satu model pembelajaran kompleks dalam pembelajaran kelompok yang mengharuskan siswa untuk menggunakan skill berpikir level tinggi. Dalam GI, guru bertugas untuk menginisiasi pembelajaran dengan menyediakan kontrol terhadap para siswa untuk memilih strategi penelitian yang akan mereka gunakan. Model pembelajaran ini bisa diterapkan untuk semua tingkatan kelas dan bidang materi pelajaran. Para siswa mengikuti investigasi mendalam terhadap berbagai topik/subtopik yang telah dipilih, kemudian menyiapkan dan menyajikan suatu laporan di secara keseluruhan (Mansur, 2013: 292). Sintak model pembelajaran GI yaitu (1) seleksi topik, (2) perencanaan kerja sama, dan (3) impelementasi. Dalam penelitian ini, dalam melakasanakan pembelajaran dengan

GI akan didukung dengan menggunakan media pembelajaran Virtual Box. Oracle VM Virtual Box adalah perangkat lunak virtualisasi, yang dapat digunakan untuk mengeksekusi sistem operasi "tambahan" di dalam sistem operasi "utama" (Wakhid, 2011) . Virtual Box merupakan salah satu aplikasi berbasis open sources, yaitu aplikasi legal dan tidak berbayar sehingga bisa dengan mudah mendapatkannya tanpa perlu membeli aplikasi tersebut. Banyak jenis aplikasi virtualisasi, tetapi untuk menggunakan aplikasi selain Virtual Box tersebut pengguna harus membeli. Selain itu Virtual Box memiliki fitur yang cukup lengkap, stabil dan mudah digunakan oleh berbagai kalangan.

\section{METODE}

Pendekatan penelitian yang digunakan adalah Penelitian Tindakan Kelas (PTK). Subjek penelitian ini adalah siswa kelas X MM1 SMK N 6 Surakarta, yang berjumlah 32 siswa, terdiri dari 25 siswa perempuan dan 7 siswa lakilaki. Data yang dikumpulkan untuk kebutuhan penelitian ini terbagi dalam dua jenis yaitu data kualitatif dan data kuantitatif. Data kualitatif tersebut meliputi data hasil observasi dan wawancara seputar proses pembelajaran di kelas, sedangkan data kuantitatif berupa nilai hasil belajar siswa dari tiap siklus. Pengumpulan data yang digunakan dalam penelitian ini yaitu (1) wawancara, (2) metode observasi, (3) metode dokumentasi, dan (4) tes. Data yang telah dikumpulkan akan dianalisis dengan analisis komparatif yaitu membandingkan nilai dari setiap siklus pada tes hasil belajar dan deskriptif kualitatif berdasarkan pada hasil observasi untuk keaktifan belajar.

\section{HASIL PENELITIAN DAN PEMBAHASAN}

Pada penelitian ini dilaksanakan prasiklus sebelum melakukan tindakan penelitian. Pada pelaksanaan tahap ini dilakukan selama satu kali pertemuan. Tahap prasiklus dilaksanakan dengan tujuan untuk memperoleh gambaran awal hasil dan aktivitas belajar siswa dalam pembelajaran sistem operasi kelas X MM1 SMK N 6 Surakarta sebelum dilakukan tindakan penelitian serta untuk mengetahui perbandingan hasil pembelajaran antara metode konvensional dengan model Group Investigation dan media pembelajaran Virtual Box. Tahap prasiklus dilaksanakan pada tanggal 1 April 2016 pukul 09.00 WIB sampai pukul 11.30 WIB pada

Kompetensi Dasar (KD) "Memahami Struktur Sistem Operasi Open Source". Dalam tahap prasiklus diketahui bahwa kegiatan pembelajaran pada prasiklus ini masih berpusat pada guru, penggunaan media pembelajaran masih kurang, siswa juga terlihat kurang aktif mengikuti pelajaran.

Dari hasil observasi terhadap kekatifan belajar siswa yang dilakukan, dari 6 aspek yang diamati yaitu (1) aspek visual, (2) aspek lisan, (3) aspek mendengarkan, (4) aspek menulis, (5) aspek mental, dan (6) aspek emosipnal, diketahui bahwa 40,63\% dari jumlah siswa yaitu 32 siswa telah melakukan aktivitas visual, 
3,13\% dari jumlah siswa telah melakukan aktivitas lisan, 70,31\% dari jumlah siswa telah melakukan aktivitas mendengarkan, 78,13\% dari jumlah siswa telah melakukan aktivitas menulis, $100 \%$ dari jumlah siswa telah melakukan aktivitas mental, dan 25\% dari jumlah siswa telah melakukan aktivitas emosional. Rata-rata ketuntasan untuk keaktifan belajar pada tahap prasiklus masih dibawah indikator keberhasilan penelitian yang diterapkan pada penelitian ini sebesar $75 \%$ yaitu hanya $52,87 \%$. Presentase ketuntasan hasil belajar pada $2,54 \mathrm{~cm}$ tahap prasiklus juga masih rendah, yaitu untuk ranah kognitif sebesar $18,75 \%$, ranah afektif $21,87 \%$, dan ranah psikomotor

$43,75 \%$.

Hasil wawancara yang telah dilakukan kepada guru mata pelajaran sistem operasi kelas X MM1 SMK N 6 Surakarta dan siswa kelas X MM1 SMK N 6 Surakarta pada tahap prasiklus diketahui pula bahwa dengan penerapan metode ceramah, keaktifan dan hasil belajar siswa masih rendah. Hal ini dikarenakan selama pembelajaran siswa kurang aktif dalam merespon materi yang disampaikan dan melakukan hal-hal diluar proses pembelajaran seperti mengobrol atau bermain laptop. Selain itu juga siswa kurang memahami materi karena siswa kurang berminat terhadap metode ceramah yang diterapkan dan kurangnya media pembelajaran yang digunakan.

Peneliti menerapkan model pembelajaran Group Investigation dan media pembelajaran Virtual Box berdasarkan analisis pada tahap prasiklus yang telah dilakukan. Model pembelajaran Group Investigation dan media pembelajaran Virtual Box dapat membantu siswa mempelajari materi sistem operasi, khususnya pada

Kompetensi Dasar "Memahami proses booting pada Linux" yang akan dilaksanakan pada siklus I dan siklus II. Dalam penelitian ini yang bertindak sebagai pengajar adalah guru mata pelajaran sistem operasi kelas X MM1 dan peneliti berperan sebagai observer untuk mengamati berlangsungnya proses belajar mengajar.

\section{Siklus I}

Pada pelaksanaan tindakan siklus I, guru menerapkan model pembelajaran Group Investigation dan media pembelajaran Virtual Box. Proses pembelajaran ini guru hanya menyampaikan materi yang akan dipelajari dan memberikan materi secara umum, bertindak sebagai nara sumber dan fasilitator, melihat bahwa siswa bisa melaksanakan tugas, membantu kesulitan yang dihadapi siswa dalam pembelajaran. Kegiatan pembelajaran lebih dipusatkan pada peran serta dan keaktifan siswa dalam kegiatan praktik menggunakan Virtual Box dan investigasi topik bahasan dalam diskusi kelompok.

Pada siklus I siswa dibagi menjadi 8 kelompok dan masingmasing kelompok beranggotakan 4 siswa. Awal pembelajaran pertemuan 1, guru memberikan pengantar materi yang akan diinvestigasi, kemudian siswa bergabung dengan kelompok masing-masing yang telah dibagi. Selanjutnya setiap kelompok diberikan tugas untuk melakukan instalasai Virtual Box dan sistem operasi Linux yang akan digunakan selanjutnya pada pertemuan 2 . Pada pertemuan kedua, siswa melakukan investigasi materi yang telah diberikan dengan menggunakan media pembelajaran Virtual Box dengan kelompok masing-masing. Setelah investigasi selesai, setiap kelompok membuat laporan hasil investigasi yang akan digunakan sebagai nilai psikomotor. Observer melakukan kegiatan observasi mengenai keaktifan dan afektif siswa. Pada akhir siklus I dilaksanakan tes tertulis untuk mengetahui nilai ranah kognitif siswa. Keaktifan belajar siklus I dapat dilihat pada Tabel 1 dan hasil belajar siklus I dapat dilihat pada Tabel 2.

Tabel 1. Keaktifan Belajar Siklus I

\begin{tabular}{cl}
\hline Aspek yang diamati & $\begin{array}{l}\text { Presentase } \\
(\%)\end{array}$ \\
\hline Visual & 81,25 \\
Lisan & 39,06 \\
Mendengarkan & 85,94 \\
Menulis & 81,25 \\
Mental & 100 \\
Emosional & 78,13 \\
Rata-rata ketuntasan & 77,61 \\
\hline
\end{tabular}

Tabel 1 mengenai hasil keaktifan belajar siklus I tersebut dilihat dari presentase ketuntasan dari data observasi yang telah dilakukan.

Tabel 2. Hasil Belajar Siklus I 


\begin{tabular}{ccc}
\hline Hasil Belajar & $\begin{array}{c}\text { Ratarata } \\
\text { Nilai }\end{array}$ & $\begin{array}{c}\text { Rata-rata } \\
\text { Ketuntasan } \\
(\%)\end{array}$ \\
\hline Kognitif & 62,5 & 18,75 \\
Afektif & 65,27 & 21,87 \\
Psikomotor & 73,44 & 43,75 \\
\hline
\end{tabular}

Keaktifan belajar siklus I masih terdapat aspek yang belum memenuhi indikator keberhasilan yaitu aspek lisan. Sedangkan hasil belajar baik ranah kognitif, afektif, maupun psikomotor juga belum memenuhi indikator keberhasilan sebesar $75 \%$.

\section{Siklus II}

Pada siklus II, dilaksanakan kegiatan investigasi kelompok menggunakan media pembelajaram Virtual Box, sama dengan siklus I. Pembagian kelompok pada siklus II juga sama dengan siklus I. Perbedaan pada siklus II yaitu ketika setiap kelompok sudah selesai melaksanakan investigasi, laporan investigasi ditampilkan dengan slide presentasi yang kemudian dijelaskan oleh masing-masing kelompok di depan kelas. Kelompok yang mendapat giliran presentasi akan ditanya oleh satu kelompok lain yang bertugas sebagai penanya inti. Slide presentasi dan kegiatan presentasi ini dijadikan sebagai nilai psikomotor. Observer mengamati keaktifan dan afektif siswa selama pembelajaran berlangsung. Pada akhir siklus II dilaksanakan tes tertulis untuk mendapat nilai kognitif siswa. Keaktifan belajar siklus II dapat dilihat pada Tabel 3 dan hasil belajar siklus II dapat dilihat pada Tabel 4.

Tabel 3. Keaktifan Belajar Siklus II

\begin{tabular}{cc}
\hline Aspek yang diamati & Presentase (\%) \\
\hline Visual & 84,38 \\
Lisan & 78,13 \\
Mendengarkan & 95,31 \\
Menulis & 81,25 \\
Mental & 100 \\
Emosional & 81,25 \\
Rata-rata ketuntasan & 86,72 \\
\hline
\end{tabular}

Tabel 3 mengenai hasil keaktifan belajar siklus II tersebut dilihat dari presentase ketuntasan dari data observasi yang telah dilakukan.

Tabel 4. Hasil Belajar Siklus II

\begin{tabular}{llc}
\hline Hasil Belajar & $\begin{array}{l}\text { Ratarata } \\
\text { Nilai }\end{array}$ & $\begin{array}{l}\text { Rata-rata } \\
\text { Ketuntasan } \\
(\%)\end{array}$ \\
\hline Kognitif & 87,5 & 81,25 \\
Afektif & 82,5 & 84,38 \\
Psikomotor & 80,47 & 87,5 \\
\hline
\end{tabular}

Keaktifan dan hasil belajar siswa pada siklus II secara keseluruhan telah memenuhi indikator keberhasilan sebesar $75 \%$.

\section{Perbandingan Hasil Tindakan}

Penerapan model Group Investigation dan media pembelajaran Virtual Box terjadi peningkatan tiap siklusnya. Perbandingan hasil dari siklus I sampai siklus II dapat dilihat pada Tabel 5 untuk keaktifan belajar, dan Tabel 6 untuk hasil belajar. Sedangkan gambar perbandingan tiap siklus dapat dilihat pada Gambar 1 untuk keaktifan belajar, dan Gambar 2 untuk hasil belajar.

Tabel 5 Perbandingan Keaktifan Belajar

\begin{tabular}{ccc}
\hline $\begin{array}{c}\text { Aspek yang } \\
\text { diamati }\end{array}$ & $\begin{array}{c}\text { Ketuntasan } \\
\text { Siklus I } \\
(\%)\end{array}$ & $\begin{array}{c}\text { Ketuntasan } \\
\text { Siklus II } \\
(\%)\end{array}$ \\
\hline Visual & 81,25 & 84,38 \\
Lisan & 39,06 & 78,13 \\
Mendengarkan & 85,94 & 95,31 \\
Menulis & 81,25 & 81,25 \\
Mental & 100 & 100 \\
Emosional & 78,13 & 81,25 \\
\hline
\end{tabular}




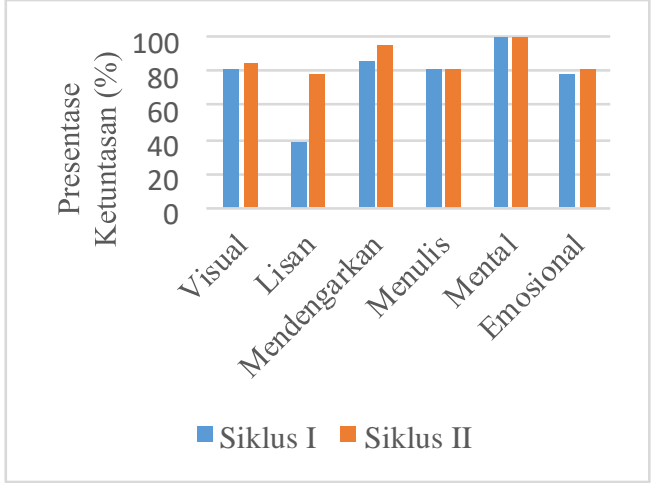

Gambar 1. Perbandingan Keaktifan Belajar

Tabel 6. Perbandingan Hasil Belajar

\begin{tabular}{ccc}
\hline Hasil Belajar & $\begin{array}{c}\text { Rata-rata } \\
\text { Nilai } \\
\text { Siklus I }\end{array}$ & $\begin{array}{c}\text { Ratarata } \\
\text { Nilai } \\
\text { Siklus II }\end{array}$ \\
\hline Kognitif & 62,5 & 87,5 \\
Afektif & 65,27 & 82,5 \\
Psikomotor & 73,44 & 80,47 \\
\hline
\end{tabular}

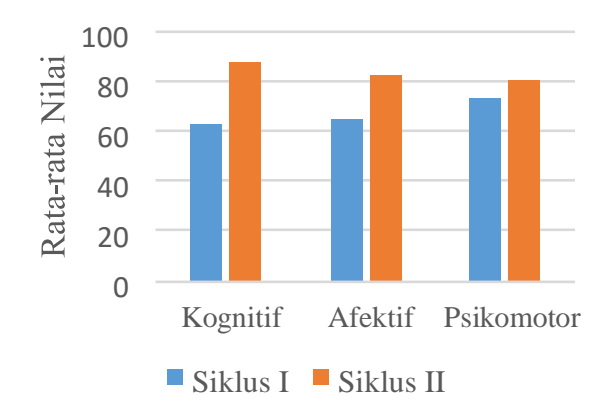

Gambar 2. Perbandingan Hasil Belajar

Peningkatan dari tahap prasiklus sampai siklus II dilihat dari presentase ketuntasannya dapat dilihat pada Tabel 7.

Tabel 7. Peningkatan Hasil Penelitian

\begin{tabular}{ccc}
\hline Aspek & & $\begin{array}{c}\text { Peningkatan } \\
\text { Ketuntasan }(\%)\end{array}$ \\
\hline Hasil Belajar & Kognitif & 62,5 \\
& Afektif & 62,51 \\
& Psikomo & 47,5 \\
& -tor & \\
Keaktifan & & 33,85 \\
\hline
\end{tabular}

Dari data tersebut dapat disimpulkan bahwa penerapan model pembelajaran Group Investigation dan media pembelajaran Virtual Box dapat meningkatkan keaktifan dan hasil belajar siswa. Penerapan model pembelajaran Group Investigation pada penelitian ini yaitu dengan melaksanakan kegiatan presentasi kelompok dimana setiap kelompok yang maju di depan kelas mempresentasikan hasil investigasinya akan ditanya oleh kelompok lain yang bertugas sebagai penanya inti. Kegiatan presentasi seperti ini terbukti mampu meningkatkan keaktifan dan hasil belajar siswa karena siswa yang berperan sebagai presentator dituntut menjelaskan hasil investigasi kelompoknya di depan kelas, sehingga siswa lebih mengerti materi yang diinvestigasi, serta menjadikan siswa lebih bertanggung jawab terhadap dirinya sendiri maupun kelompoknya dan siswa yang berperan sebagai penanya inti juga akan lebih kritis dalam menanggapi kegiatan presentasi serta akan mendapatkan jawaban dari materi yang belum dimengerti melalui pertanyaan-pertanyaan yang disampaikan. Sedangkan media pembelajaran Virtual Box membantu siswa lebih memahami materi pada mata pelajaran sistem operasi karena siswa langsung mempraktikkan materi pembelajaran, mencari informasi, dan mengumpulkan data terkait materi yang diinvestigasi serta membantu meningkatkan keaktifan dan hasil belajar siswa karena siswa berperan aktif selama proses belajar mengajar dengan media Virtual Box yang digunakan.

\section{SIMPULAN DAN SARAN}

Berdasarkan hasil penelitian yang telah dilakukan, maka dapat disimpulkan bahwa (1) penerapan model pembelajaran Group Investigation dan media pembelajaran Virtual Box dapat meningkatkan keaktifan belajar siswa pada mata pelajaran sistem operasi kelas X MM SMK N 6 Surakarta dengan presentase peningkatan sebesar 33,85\% dilihatdari rata-rata ketuntasan pada tahap prasiklus sampai siklus II, (2) penerapan model pembelajaran Group Investigation dan media pembelajaran Virtual Box dapat meningkatkan hasil belajar siswa pada mata pelajaran sistem operasi kelas X MM SMK N 6 Surakarta dengan presentase peningkatan ketuntasan sebesar $62,5 \%$ untuk ranah kognitif, $62,51 \%$ untuk ranah afektif, dan $47,75 \%$ untuk ranah psikomotor, dan (3) kegiatan presentasi kelompok dari hasil penerapan model pembelajaran Group Investigation dan media 
pembelajaran Virtual Boxberhasil meningkatkan keaktifan danhasil belajar siswa kelas X MM SMK N 6 Surakarta.

Dari kesimpulan yang telah dipaparkan, dapat diajukan beberapa saran yang pertama untuk sekolah hendaknya memberikan dukungan kepada guru untuk menyajikan pembelajaran inovatif seperti model pembelajaran Group Investigation serta menggunakan media pembelajaran seperti Virtual Box. Kedua kepada guru sebaiknya menyampaikan pembelajaran menggunakan model pembelajaran yang dapat membuat siswa aktif dan lebih memahami materi pembelajaran seperti model pembelajaran Group Investigation supaya keaktifan dan hasil belajar siswa dapat mencapai hasil yang maksimal serta sebaiknya guru menggunakan media pembelajaran yang menarik seperti Virtual Box agar siswa tidak jenuh selama pembelajaran serta dapat meningkatkan keaktifan dan hasil belajar. Ketiga kepada siswa sebaiknya lebih rajin belajar dan berani menyampaikan pendapat, ide, atau pertanyaan juga siswa lebih menghargai guru yang sedang menjelaskan materi di depan kelas dengan tidak melakukan hal-hal diluar proses pembelajaran seperti bermain laptop sendiri atau berbicara dengan teman.

\section{DAFTAR PUSTAKA}

Direktorat Jendral Pendidikan Dasar dan Menengah, Kementrian Pendidikan dan Kebudayaan. (2015). Panduan
Penilaian pada Sekolah Menengah

Kejuruan. Jakarta:

Kementrian Pendidikan dan Kebudayaan.

Istikomah, H., Hendratto, S., Bambang, S. (2010).

enggunaan Model Pembelajaran

Group Investigation untuk

Menumbuhkan Sikap Ilmiah

Siswa. Jurnal Pendidikan Fisika Indonesia, 6, 40.

Mansur. (2013). Melaksanakan PTK (Penelitian Tindakan Kelas) itu Mudah

(Classroom

Action Research). Jakarta : Bumi Aksara.

Sharan, Y. \&Sharan, S. 1989. Group Investigation Expands Cooperative Learning. Assosiation for Supervision and Curriculum Development, hlm. 17.

Wakhid. (2011). Menginstall OS

Dengan Virtual Box

(DasardasarMenggunakan Virtual

Box). Diperoleh 31 Desember

2015, dari http://system32.web.id

Yunita, Nurhayati, N.D., \&Mulyani,

$\begin{array}{lrr}\text { S. } & \text { (2015). } & \text { Peningkatan } \\ \text { Aktivitas } & \text { dan } & \text { Prestasi } \\ \text { Belajar } & \text { Siswa } & \text { Melalui }\end{array}$

Penerapan Model Pembelajaran Group Investigation (Gi) Pada Materi

Kelarutan dan Hasil Kali Kelarutan Kelas Xi Semester Genap SMA Negeri Kebakkramat TahunPelajaran 2014/2015. Jurnal Pendidikan Kimia, 4 (4), 117-122. 